Boise State University

ScholarWorks

7-2021

\title{
Using an Ultraviolet Light Test to Improve Sagebrush Identification and Predict Forage Quality for Wildlife
}

Roger Rosentreter

Boise State University

Brecken C. Robb

Boise State University

Jennifer S. Forbey

Boise State University 


\title{
Using an ultraviolet light test to improve sagebrush identification and predict forage quality for wildlife
}

\author{
Roger Rosentreter ${ }^{1, *}$, Brecken C. RobB ${ }^{1}$, And Jennifer S. Forbey ${ }^{1}$ \\ ${ }^{1}$ Boise State University, Biological Sciences Department, 1910 University Drive, Boise, ID 83725
}

\begin{abstract}
Sagebrush identification can be improved by using a relatively easy ultraviolet (UV) light test on specimens. Sagebrush produces a variety of water-soluble polyphenols called coumarins, which fluoresce a blue color under UV light and can help differentiate species, subspecies, and hybrids. We tested 16 different sagebrush taxa (including species and subspecies) from herbarium specimens and found 3 taxa (low sagebrush, Artemisia arbuscula; Wyoming sagebrush, A. tridentata wyomingensis; and basin sagebrush, A. $t$. tridentata) that were often misidentified. We show that the UV light test can greatly improve identification of these species. Moreover, given that the UV+ chemicals that discriminate taxa are also considered an indirect biomarker of sagebrush palatability for some herbivores, the UV light test can be used to predict forage quality for threatened species like sage-grouse (Centrocercus spp.) and pygmy rabbits (Brachylagus idahoensis). Collecting voucher specimens of sagebrush at wildlife study sites and comparing their UV intensity to historical herbarium specimens could help identify both current and changing availability of palatable sagebrush for wildlife. We found that even herbarium specimens $>80$ years old still fluoresce under UV light.
\end{abstract}

RESUMEN.-La identificación de la artemisa se puede mejorar utilizando en las muestras una prueba de luz ultravioleta relativamente fácil. La artemisa produce una variedad de polifenoles solubles en agua llamados cumarinas que emiten un color azul fluorescente bajo luz ultravioleta (UV), que pueden ayudar a diferenciar entre especies, subespecies e híbridos. Analizamos 16 taxones diferentes de artemisa de especímenes de herbario (incluidas especies y subespecies) y encontramos tres taxones (bajo, Artemisia arbuscula; Wyoming, A. tridentata wyomingensis; cuenca, A. $t$. tridentata) que a menudo no eran identificadas correctamente. Demostramos que la prueba de luz ultravioleta puede mejorar ampliamente la identificación de estas especies. Adicionalmente, debido a que los productos químicos ultravioleta que distinguen taxones también se consideran un biomarcador indirecto de la palatabilidad de la artemisa para algunos herbívoros, la prueba de luz ultravioleta se puede utilizar para predecir la calidad del forraje para especies amenazadas, tales como la salvia (Centrocercus spp.) y los conejos pigmeos (Brachylagus idahoensis). La recolección de muestras de artemisa en los sitios de estudio de vida silvestre y la comparación de la intensidad de luz ultravioleta con las muestras históricas de especímenes de herbario podría ayudar a identificar la disponibilidad actual y futura de artemisa palatable para los herbívoros de vida silvestre. Descubrimos que las muestras de herbario de más de 80 años aún presentan fluorescencia bajo la luz ultravioleta.

Across the Intermountain West there are nearly 2 dozen species of sagebrush (Artemisia spp.), and within each species there are several subspecies and hybrids, as well as chemical and structural diversity within individual plants (Rosentreter 2005, Frye et al. 2013, Fremgen-Tarantino et al. 2020). This makes the identification of sagebrush at the species level extremely tedious and challenging. Many species are misidentified when research personnel lack strong taxonomic expertise; local knowledge of morphological variation, phenology, and soil conditions relative to sagebrush; and access to genetic tools. Recognizing the biological and environmental significance of sagebrush is straightforward, but identifying its heterogeneous functionality and palatability for wildlife is not. To foraging herbivores, not all sagebrush taxa are created equal. Proper identification of the type and diversity of sagebrush species within and among habitats is critical to our knowledge regarding all sagebrush-associated wildlife.

Sagebrush provides food and habitat for several desert-dwelling species, including pronghorn (Antilocapra americana), elk (Cervus canadensis), mule deer (Odocoileus hemionus), pygmy rabbits (Brachylagus idahoensis), sage-grouse

*Corresponding author: roger.rosentreter0@gmail.com 
(Centrocercus urophasianus and C. minimus), and many insects (Welch 2005). Mostly a semievergreen shrub, sagebrush can withstand cold harsh winters and hot dry summers, consequently providing food to wildlife year-round. This persistence allows for some of these animal species, including sage-grouse, to be sagebrush obligates during large portions of the year (Knick and Connelly 2011). This renders sagebrush a critical conservation species, especially for the restoration of sage-grouse habitats (Connelly et al. 2000).

Sagebrush plants produce a variety of water-soluble polyphenols called coumarins (Shafizadeh and Melnikoff 1970) that fluoresce a blue color under ultraviolet (UV) light. Coumarins can help differentiate species, subspecies, and hybrids (Stevens and McArthur 1974, McArthur et al. 1988, Wilt et al. 1992, McArthur and Sanderson 1999a, Shultz 2012, Richardson et al. 2018). Richardson et al. (2018) demonstrated that coumarin content differs significantly between mountain sagebrush (Artemisia t. vaseyana) and other big sagebrush species (i.e., basin [A. $t$. tridentata], Wyoming [A. t. wyomingensis]), but not between basin and Wyoming sagebrush. McArthur et al. (1988) showed that coumarin content differs significantly among mountain and basin sagebrush and their hybrids. While polyphenols, including coumarins, can vary seasonally (Wilt and Miller 1992), coumarin content remains distinct between sagebrush species regardless of season (Olsoy et al. 2020).

Coumarin fluorescence is also an indicator of sagebrush diet selection by wildlife. Determining differences in coumarin concentrations among plants may allow for a better understanding of habitat use by sagebrush obligates like sage-grouse and economically important big-game species like mule deer. For example, the sagebrush species preferred by mule deer (i.e., mountain, low [A. arbuscula], silver [A. cana]) generally have higher coumarin concentrations than less preferred species do (i.e., Wyoming, basin; Sheehy and Winward 1981, Wambolt 2001). Similarly, sagebrush species foraged on by sage-grouse in higher proportion than their availability (e.g., black [A. nova] in Frye et al. 2013 and mountain in Welch et al. 1991) have higher coumarin concentrations than avoided plants do (e.g., Wyoming). Sage-grouse, like other avian species, have UV photoreceptors in their eyes
(Hart 2001, Hart and Hunt 2007) that may permit them to see into the UV spectrum and therefore use coumarins as a cue for diet quality. To test this idea, Rosentreter (2005) used a UV light test in the field to link coumarin content in 23 different sagebrush taxa with data on dietary preference of sagebrush taxa by sage-grouse. This study, based on literature and personal experience of several Artemisia experts, indicated that UV fluorescence is an indirect biomarker of sagebrush palatability. However, in contrast to protein and monoterpenes (Frye et al. 2013, Ulappa et al. 2014, Wing and Messmer 2016, Fremgen-Tarantino et al. 2020), coumarins have not been explicitly examined to explain diet selection by wildlife.

The UV light test is an efficient and effective way of increasing confidence in sagebrush identification and potentially in predicting palatability, yet it is not widely used. To demonstrate its taxonomic value, we used the UV test with 16 different sagebrush species obtained from herbarium specimens. We aim to promote the UV test as an additional tool in identifying sagebrush species and in directing management to conserve habitats with potentially palatable plants for wildlife.

\section{METHODS}

We evaluated 55 sagebrush herbarium specimens, with the goal of having at least 3 specimens of each sagebrush taxon found in the Intermountain West. This was accomplished for all but 3 species (i.e., 1 species was represented by only 1 specimen and it was later revealed that 1 other specimen had been misidentified; the other 2 species were represented by fewer than 3 specimens after the study determined that the chosen specimens had been misidentified). Pressed specimens in good condition (i.e., included most plant parts, pressed and dried properly, labeled thoroughly) were obtained from the Snake River Plain (SRP) herbarium at Boise State University (Boise, Idaho, USA). Although sagebrush is a commonly collected plant at the SRP herbarium, many specimens were spring and early summer collections that did not have flower stalks or flowers included in the collection, which are required to verify species classification. Moreover, some specimens lacked enough leafy material to justify the removal of 
leaves for testing without degrading the specimen. To keep sample quality relatively consistent across species while considering these limitations, we kept sample sizes small. However, we feel that the sample size of at least 3 specimens for each taxon was large enough to demonstrate the broad variation of coumarin content across the spectrum of Artemisia species and that it illustrated the ease with which sagebrush species and subspecies can be discriminated using the UV light test. Most specimen samples included location, date collected, elevation, and occasionally aspect. Nomenclature follows Winward (2004) and Hitchcock and Cronquist (2018).

We also focused on specimens collected by experienced plant collectors, curators, herbarium collection managers, and a few well-known sagebrush researchers. These included specimens collected by Alan Beetle, who helped describe Artemisia tridentata subspecies wyomingensis, and Leila Shultz, who authored a taxonomic treatment on the genus Artemisia in the Flora of North America (Shultz 2006). Specimens also included those collected by R.R. Halse, R.B. Ferguson, R. Rosentreter, B. Ertter, J.F. Smith, C. Brown, D. Atwood, B. Zamora, J. Grimes, M.T. Dunn, E. Neese, K. Whited, A. Pinzl, M. Mancuso, A. DeBolt, W. Cottam, W.E. Booth, and L. Thornton. The oldest specimen was collected by W. Cottam in 1933. The collectors' names and initials given here are the same as listed on their plant labels. Leila Shultz and Roger Rosentreter were the only 2 collectors who included UV light test results on their annotated herbarium labels. It is assumed that none of the other specimens were tested for UV fluorescence. Once standard specimen requirements were met, the final specimens used for testing were chosen randomly.

The specimens were evaluated in a room in the SRP herbarium for more controlled conditions and to prevent the exposure of any herbarium specimens to outdoor conditions, but these same tests could be performed in the field. The room temperature was around $21{ }^{\circ} \mathrm{C}$ and $30 \%$ humidity. The windows were tightly closed and covered to maintain darkness. Each herbarium specimen was processed by removing 3-8 leaves, depending on the leaf size, and placing the leaves in a capped $20-\mathrm{mL}$ glass scintillation vial filled with $10 \mathrm{~mL}$ of deionized water. Each vial was placed into a $3 \mathrm{D}$-printed vial holder that could hold up to 4 vials and had a slot below that held a UV light (emitting at a 395-nm wavelength), ensuring equal light distribution (Fig. 1).

The leaves from each specimen remained in water for at least $2 \mathrm{~min}$ and then were lightly shaken to homogenize the extracted coumarins prior to visualization of UV fluorescence. Three specimens of the same sagebrush species were analyzed simultaneously, alongside the standard scopoletin $(0.437 \mathrm{mg} / \mathrm{mL})$, which served as a UV fluorescent standard for consistent baseline comparison. The scopoletin standard was made fresh for each testing session to maintain consistency and to avoid any potential light degradation. The 4 vials were then placed in a blackout box with a heavy curtain entrance, and the UV light was switched on, causing the samples to fluoresce varying degrees of blue depending on the concentration of coumarins present. Each sample was then rated relative to the scopoletin standard on a scale of $0-4$, corresponding to no fluorescence (0), weak fluorescence barely detected (1), fluorescence detected (2), strong fluorescence (3), and very strong fluorescence (4), with scopoletin equating to strong fluorescence (3). This ranking was used to compare qualitatively to the UV ranking proposed in Rosentreter (2005; colorless, light, moderate, strong, and intense). Any specimen with UV fluorescence that was inconsistent with its labeled species determination was considered misidentified and was reclassified only after R. Rosentreter confirmed morphological characteristics and information on environmental conditions (e.g., soil, elevation) at the collection site.

\section{RESUlTS}

We confirmed that herbarium specimens continue to have UV reactions, regardless of their age. One specimen from 1933 still provided a positive UV reaction. Results of the UV light test, scientific names, and any changes in species identification of herbarium specimens are outlined in Table 1 . Of the 55 herbarium specimens we investigated, representing 16 species or subspecies, the UV light test results and the specimens' morphological features indicated that $18 \%$ were misidentified. Specimens labeled as Wyoming sagebrush and low sagebrush were the most frequently misidentified species. Most specimens labeled as Wyoming sagebrush were determined to be 


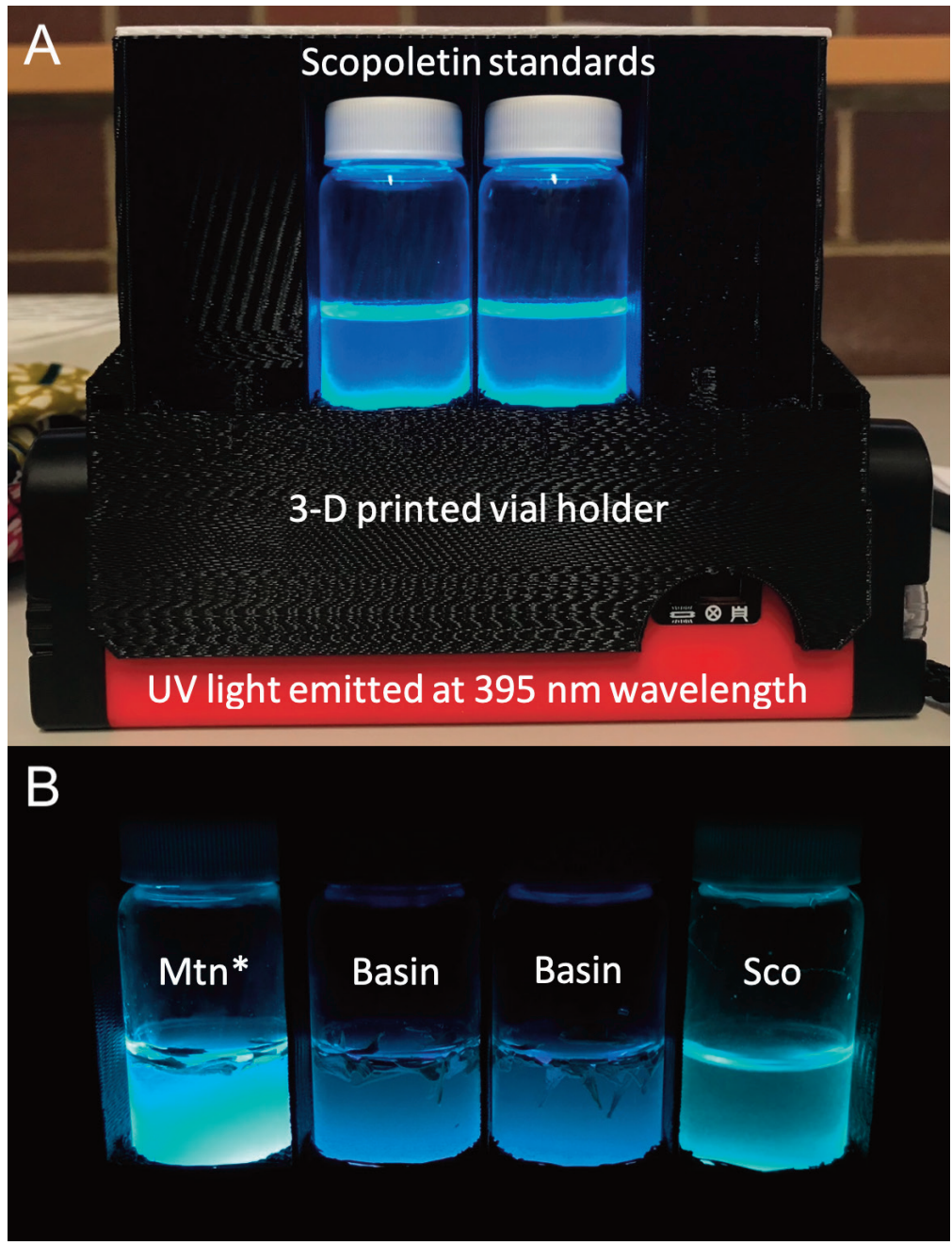

Fig. 1. An example of measuring the coumarin content in Artemisia specimen voucher samples. A, Setup for the UV light test. Each scintillation vial holds leaves from one individual herbarium specimen and is filled with deionized water. The 3D-printed vial holder held up to 4 vials along with a UV light emitting at a 395-nm wavelength. B, Three specimens labeled as basin big sagebrush (Artemisia tridentata ssp. tridentata). The specimen on the far left (labeled with an asterisk) was reclassified to mountain big sagebrush (A. t. vaseyana) based on the UV light test and morphology of the leaf and flower stalk. "Sco" = scopoletin standard.

mountain sagebrush, and one was determined to be subalpine sagebrush (Table 1). All of the misidentified low sagebrush specimens were determined to be early sagebrush. All of the misidentified basin big sagebrush specimens were determined to be mountain sagebrush.

The strongest UV reaction was from subalpine sagebrush, followed by early sagebrush and mountain sagebrush (Table 1 ), which is consistent with Rosentreter (2005). The single plant identified as low sagebrush (based on morphology) did not have a UV reaction, which was inconsistent with the expected moderate UV reaction described in Rosentreter (2005). Pygmy and Owyhee (also known as "fuzzy") sagebrush specimens were consistently UV negative (Table 1). Rosentreter (2005) demonstrated a colorless UV result for Owyhee sagebrush but a moderate UV result for pygmy sagebrush. Of the species with weak (rank of 1 ) to moderate (rank of 2) UV reactions, 4 species (silver, Wyoming, basin, and bud sage) were relatively higher than indicated in Rosentreter (2005). Bigelow sagebrush was relatively lower than 
TABLE 1. Sampled herbarium specimens of Artemisia species and subspecies in order of relative UV reaction by species determined. Headers include common name (based on UV fluorescence and morphology), species determined (based on UV fluorescence, morphology, and elevation/habitat), species labeled (in herbarium), and relative UV reaction (no fluorescence [0], weak fluorescence barely detected [1], fluorescence detected [2], strong fluorescence [3], and very strong fluorescence [4]). Bolded type indicates a correction from what the species was originally labeled on the herbarium specimen to the revised species based on UV reaction and morphology of the specimen. "A." = Artemisia, " $t$." = tridentata, “a." = arbuscula.

\begin{tabular}{|c|c|c|c|c|}
\hline Common name & Species determined & Species labeled & $\begin{array}{l}\text { Relative UV } \\
\text { reaction }\end{array}$ & $\begin{array}{l}\text { Specimen ID } \\
\text { number }\end{array}$ \\
\hline \multirow[t]{2}{*}{ Subalpine big sagebrush } & A. $t$. spiciformis & A.t. spiciformis & 4 & 11477 \\
\hline & A.t. spiciformis & A.t. wyomingensis & 4 & 7757 \\
\hline \multirow[t]{10}{*}{ Early sagebrush } & A. a. longiloba & A. a. longiloba & 3 & $73-629$ \\
\hline & A. a. longiloba & A. a. longiloba & 3 & 8436 \\
\hline & A. a. longiloba & A. a. longiloba & 3 & 11627 \\
\hline & A. a. longiloba & A. a. longiloba & 3 & 16729 \\
\hline & A. a. longiloba & A. a. longiloba & 3 & 19546 \\
\hline & A. a. longiloba & A. a. longiloba & 3 & 19600 \\
\hline & A. a. longiloba & A. arbuscula & 3 & 9867 \\
\hline & A. a. longiloba & A. arbuscula & 3 & 12501 \\
\hline & A. a. longiloba & A. arbuscula & 3 & 20058 \\
\hline & A. a. longiloba & A. arbuscula & 3 & 21965 \\
\hline \multirow[t]{8}{*}{ Mountain big sagebrush } & A. $t$. vaseyana & A. $t$. vaseyana & 2 & 9843 \\
\hline & A. t. vaseyana & A. $t$. vaseyana & 2 & 19599 \\
\hline & A. $t$. vaseyana & A. $t$. vaseyana & 2 & 19616 \\
\hline & A.t. vaseyana & A. $t$. wyomingensis & 2 & 11545 \\
\hline & A.t. vaseyana & A. $t$. tridentata & 3 & 95 \\
\hline & A.t. vaseyana & A. $t$. tridentata & 3 & 14374 \\
\hline & A.t. vaseyana & A. t. wyomingensis & 3 & 8350 \\
\hline & A.t. vaseyana & A. t. wyomingensis & 3 & 11464 \\
\hline \multirow[t]{3}{*}{ Xeric big sagebrush } & A. $t$.xericensis & A. t.xericensis & 2 & $842 \mathrm{~A}$ \\
\hline & A. $t$ xericensis & A.t.xericensis & 2 & $842 B$ \\
\hline & A. $t . x e r i c e n s i s$ & A. $t . x e r i c e n s i s$ & 2 & $842 \mathrm{C}$ \\
\hline \multirow[t]{3}{*}{ Silver sagebrush } & A. cana viscidula & A. cana viscidula & 2 & 9855 \\
\hline & A. cana viscidula & A. cana viscidula & 2 & 16726 \\
\hline & A. cana viscidula & A. cana viscidula & 2 & 16989 \\
\hline \multirow[t]{3}{*}{ Black sagebrush } & A. nova & A. nova & 1 & WM26 \\
\hline & A. nova & A. nova & 1 & 700 \\
\hline & A. nova & A. nova & 2 & no number \\
\hline \multirow[t]{3}{*}{ Bigelow sagebrush } & A. bigelovii & A. bigelovii & 1 & no number \\
\hline & A. bigelovii & A. bigelovii & 1 & 15923 \\
\hline & A. bigelovii & A. bigelovii & 1 & 16728 \\
\hline \multirow[t]{3}{*}{ Sand sagebrush } & A. filifolia & A. filifolia & 1 & 2115 \\
\hline & A. filifolia & A. filifolia & 1 & 10036 \\
\hline & A. filifolia & A. filifolia & 1 & 16012 \\
\hline \multirow[t]{3}{*}{ Fringed sagebrush } & A. frigida & A. frigida & 1 & 61 \\
\hline & A. frigida & A. frigida & 1 & $2010-0141$ \\
\hline & A. frigida & A. frigida & 1 & 3736 \\
\hline \multirow[t]{3}{*}{ Wormwood } & A. absinthium & A. absinthium & 1 & 40 \\
\hline & A. absinthium & A. absinthium & 1 & 8308 \\
\hline & A. absinthium & A. absinthium & 1 & 9846 \\
\hline Wyoming big sagebrush & A. $t$. wyomingensis & A. $t$. wyomingensis & 1 & 3124 \\
\hline \multirow[t]{3}{*}{ Basin big sagebrush } & A. $t$. tridentata & A. $t$ tridentata & 0 & 68463 \\
\hline & A. $t$ tridentata & A. $t$ tridentata & 1 & 12663 \\
\hline & A. $t$ tridentata & A. $t$ tridentata & 1 & 12676 \\
\hline \multirow[t]{3}{*}{ Bud sage ${ }^{a}$} & A. spinescens & A. spinescens & 0 & 9 \\
\hline & A. spinescens & A. spinescens & 0 & 5833 \\
\hline & A. spinescens & A. spinescens & 2 & 1655 \\
\hline Low sagebrush & A. arbuscula & A. arbuscula & 0 & 19542 \\
\hline \multirow[t]{3}{*}{ Owyhee sagebrush } & A. papposa & A. papposa & 0 & $75-20$ \\
\hline & A. papposa & A. papposa & 0 & $75-76$ \\
\hline & A. papposa & A. papposa & 0 & 10217 \\
\hline \multirow[t]{3}{*}{ Pygmy sagebrush } & A. pygmaea & A. pygmaea & 0 & 4787 \\
\hline & A. pygmaea & A. pygmaea & 0 & 16505 \\
\hline & A. pygmaea & A. pygmaea & 0 & 30823 \\
\hline
\end{tabular}




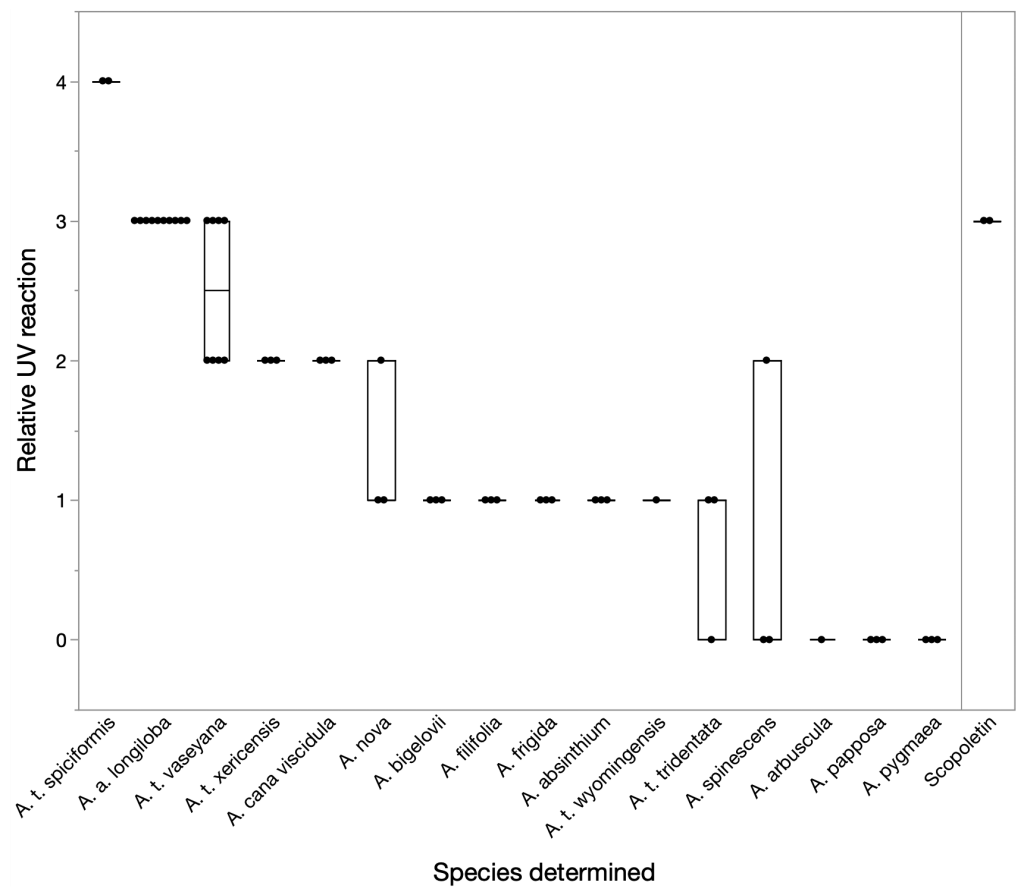

Fig. 2. Relative UV reaction for each species and subspecies after redetermining the correct species. UV reaction is relative to the scopoletin standard on a scale of $0-4$, corresponding to no fluorescence $(0)$, weak fluorescence barely detected (1), fluorescence detected (2), strong fluorescence (3), and very strong fluorescence (4), with the scopoletin standard equating to strong fluorescence (3). "A." = Artemisia, "t." = tridentata, "a." = arbuscula.

indicated in Rosentreter (2005). Fringed sagebrush, sand sagebrush, and wormwood were 3 new species not previously investigated. After correcting species identification based on morphological, chemical, and elevational characteristics, those with the greatest variation in UV reaction were bud sage, followed by mountain, black, and basin sagebrush (Fig. 2).

\section{Discussion}

Fluorescence can be used to distinguish species and subspecies of sagebrush and is related to a distinctive chemical fingerprint (Wilt and Miller 1992, Wilt et al. 1992, Richardson et al. 2018) that is genetically determined (Bajgain et al. 2011, Richardson et al. 2012, Huynh et al. 2015). The most immediate benefit of expanding the UV test is to improve identification of sagebrush for both the accuracy of preserved herbarium specimens and for targeted management of specific sagebrush species that sagebrush-obligate herbivores eat. While we analyzed only a limited number of herbarium specimens, the focus on specimens from knowledgeable, taxonomically trained collectors illustrates the difficulty of sagebrush identification, with nearly one-fifth of all herbarium specimens misidentified. Other advancing (yet more expensive) technologies, such as nearinfrared spectroscopy, further demonstrate the regular misidentification of sagebrush in the field (Robb 2020). The most common misidentifications were in the subspecies of big sagebrush (A. tridentata), which is also the taxonomic group for which the addition of the UV test to the evaluation of morphological features would have the most benefit. Our results suggest that herbarium specimens labeled Wyoming sagebrush that have a positive UV test could be mountain or subalpine sagebrush. Although both are found in frigid environments, mountain sagebrush has relatively less UV color, generally lacks propagation by layering, and is found in well-drained soils, compared to subalpine sagebrush, which has intense UV fluorescence, propagates by layering, and is found in deep soils with frequent snowdrifts (Winward 2004, Rosentreter 2005). The subalpine sagebrush specimen that was 
reclassified from Wyoming sagebrush was intense in its UV color reaction and was collected from $>9200$ feet $(2805 \mathrm{~m})$, not at a lower or midelevation range, where mountain sagebrush is found. Coupled with the UV test, these additional observations of collected specimens could differentiate between mountain and subalpine sagebrush. Specimens with morphology consistent with Wyoming sagebrush but having UV fluorescence are consistent with previous work that indicates a relatively wide distribution of hybrids between Wyoming and mountain sagebrush (Goodrich et al. 1999, McArthur and Sanderson 1999a, 1999b, McArthur 2005) or a distinct taxon of big sagebrush (Winward 2004; A. tridentata hybrid B [Bonneville big sagebrush]) with unique UV fluorescence. Results also indicate that misidentification of mountain sagebrush as basin sagebrush could be minimized with a UV test, since basin sagebrush has weak to no fluorescence. Proper identification of the 3 subspecies of big sagebrush is important, given the predominance of these 3 sagebrush taxa in the Intermountain West (Turi et al. 2014), the reliance on these species for habitat restoration (Arkle et al. 2014, Requena Mullor et al. 2019), and the evidence that wildlife prefer to eat mountain sagebrush over the other subspecies (Sheehy and Winward 1981, Welch and McArthur 1986, Welch et al. 1991, Wambolt 1996, Wambolt 2001).

Chemical variation may also exist across plant populations and within a single individual plant, as the studies above indicate. Given that a limited number of leaves were available on an herbarium specimen, it is possible that there is variation among leaves within a plant based on age, leaf type, and seasonal variation in chemistry.

Low sagebrush was also misidentified relatively frequently in herbarium specimens. This misidentification may stem from the use of low sagebrush as the default classification for low-growing sagebrush with relatively small leaves. Many collectors and taxonomists use these characters as the species-level determination tool and do not treat low sagebrush as a separate species or delineate the specimen to the subspecies level. The results of the UV fluorescence and accompanying morphological characteristics indicated that many of the low sagebrush specimens were in fact early sagebrush. Low and early sagebrush often occur together, separated by soil texture and depth (Winward 2004). In addition to intense UV reactions from early sagebrush that exceed the UV reaction of low sagebrush, low sagebrush can be distinguished from early sagebrush by the "buck-toothed" center lobe on the leaf. Low sagebrush appears to have some variation in its UV fluorescence, even within the same plants and population across seasons (Olsoy et al. 2020). However, knowledge of the flowering season and leaf morphology could assist with making a proper differentiation between low and early sagebrush. Depending on the date of collection, low sagebrush can be differentiated by later phenology of flowering (September-October) compared to early sagebrush (July-August). If seed heads are included in voucher specimens, low sagebrush has smaller seed heads ( $<3 \mathrm{~mm}$ wide, flattened by a ruler) compared to early sagebrush, which has larger seed heads (>3 mm wide). Early sagebrush is worth distinguishing from low sagebrush because some of the largest sage-grouse populations (measured by lek size) occur in areas with abundant populations of early sagebrush (Rosentreter 2005). We also caution that specimens identified as low sagebrush could also be a lowgrowing mountain sagebrush; UV reaction would offer limited resolve, but leaf morphological characteristics and growth form could be used to distinguish them.

Most species and subspecies were faithful to a given UV reaction, while 4 species (mountain, basin, black, and bud sage) appeared to have relatively high UV variation (Fig. 2). Variation in UV reaction in mountain and basin sagebrush may stem from hybridization, which results in intermediate morphological and UV reactions (McArthur et al. 1988). Variation in UV reaction ratings within a species may also reflect different areas, age of plant, leaf type (e.g., persistent, or ephemeral), or season. Variation has been noted for black sagebrush;"type a" has grayer leaves and a moderate UV reaction compared to "type b," which has greener leaves and a colorless or negative UV reaction (Winward 2004, Rosentreter 2005). Our results suggest that there is variation in the reaction even within UV-positive black sagebrush. Bud sage is less common than many of the other species and is extremely easy to identify using morphological traits, so the UV reaction test has not been well studied in this group. Bud sage is totally deciduous and is not used in the 
winter as a food source, but it could be used prior to leaf senescence. The variation in colorless to moderate UV reaction suggests that bud sage would be an interesting species for more detailed chemical analysis and consideration as a food source.

Despite evidence of some misidentification, results show that a high percentage of specimens were properly classified. Researchers that take the time to collect a plant specimen and properly voucher it in an herbarium are more likely to be knowledgeable about plant taxonomy. We suspect that many published wildlife studies lacking voucher specimens have an even lower percentage of properly determined taxa. Specifically, published articles that focus on Wyoming and low sagebrush may not be accurate with respect to the type of sagebrush present in the study area unless they have vouchers and the UV reaction has been checked.

We offer guidance to improve the identification of sagebrush for studies focused on describing habitats and habitat quality for wildlife, specifically those focused on herbivores. First, wildlife studies would be improved by testing the sagebrush in the study area using a simple UV-light fluorescence analysis. For best test results, we recommend that at least 10 similar-looking sagebrush plants (i.e., similar in plant architecture and leaf morphology) should be tested independently within a study area having relatively homogeneous soil and elevation. Wildlife studies should also establish voucher specimens of the sagebrush types found in the study area. Making herbarium voucher specimens is a standard botanical technique, and information on how to do it is readily available (e.g., https:/herbarium.usu.edu/ resources/learning_about_plants/making_spe cimens). Vouchers should be properly preserved as herbarium specimens, and their reaction to UV light fluorescence should be recorded on the herbarium voucher sheet. Voucher specimens should have the elevation and aspect on the label, because some species and subspecies occur at colder elevations and aspects. Vouchers usually provide collection dates to assist in evaluating the flowering stage (phenology), and these dates can also be a diagnostic tool, such as in distinguishing early and low sagebrush. Many wildlife and range studies are conducted in the spring and summer when the flowering stage may not be developing yet, since most sagebrush species flower in the fall.
This phenology adds to the challenge when determining the species of sagebrush in the summer. Herbarium specimens can be used to confirm identification of sagebrush cited in published studies. However, very dry herbarium specimens may be slower to release chemicals from the leaf tissues than fresh material would. We recommend using room temperature or slightly warm water in the scintillation vials and lightly agitating the dried material before testing.

UV tests should include a composite of 3-5 leaves and use a general ratio of 1 leaf to $2 \mathrm{~mL}$ water. Use of glass vials is strongly recommended to maximize visualization of UV fluorescence. Plastic vials can give false readings, because many plastics will fluoresce and provide a false positive reading. There are a number of inexpensive UV lights that emit at the 395-nm wavelength (\$5-\$100). Under dark conditions, these lights can facilitate UV tests in the field for immediate classification of sagebrush specimens. UV tests can then be repeated under lab conditions when the specimens arrive at the herbarium. For both field and herbarium tests, we recommend including a coumarin standard of consistent concentration or including UV-positive (e.g., mountain sagebrush) and UV-negative (e.g., Wyoming, Owyhee, or pygmy sagebrush) controls during each test. Scopoletin was chosen as the standard coumarin for comparison because it is known to be present in the genus Artemisia (Shafizadeh and Melnikoff 1970, Wilt et al. 1992) and is commercially available at $99 \%$ purity. However, the hue of the fluorescence was slightly different than that of the coumarins found in all of the sagebrush specimens we measured (Fig. 1). Other commercially available coumarins, such as aesculin, could be included as standards that may better match the hue of sagebrush. Otherwise, mountain sagebrush offers a good alternative to a single chemical standard, given that this taxon is commonly found across landscapes and in herbaria, has strong UV fluorescence, and is the correct hue for comparison. It is important to note that a composite of mountain sagebrush collected from the same location should be used due to potential geographical variation in UV reaction (Fig. 2).

As sagebrush habitats and species composition continue to be altered and wildlife species reliant on sagebrush continue to decline, it is increasingly important to correctly identify 
sagebrush species. We must properly identify sagebrush species if we want to interpret consequences of historical and current climatic and human disturbances along with subsequent restoration practices such as reseeding (Arkle et al. 2014, Requena-Mullor et al. 2019). Moreover, we must identify palatable sagebrush species if we want to better conserve threatened herbivores like sage-grouse and pygmy rabbits that are selective toward not just sagebrush species, but the chemistry of those species. The broader use of UV tests can both improve identification of sagebrush in the field and be an indicator of relative palatability between and within sagebrush taxa, and therefore can help fill these information gaps.

\section{ACKNOWLEDGMENTS}

We would like to acknowledge many sagebrush experts who taught us what we now know. These include, but are not limited to, M. Morris, E. Tisdale, C. Wellner, A. Winward, D. McArthur, and B. Richardson. R. Kelsey was helpful in all aspects of this and other sagebrush projects that we have completed. This project originated as a class project for the Ecology of Western North American Shrubs class at Boise State University. We thank J. Smith, curator of the Snake River Plains Herbarium at Boise State University. We also thank J. Enterkine for his development and printing of the 3D vial holder, and 2 anonymous reviewers who strengthened this manuscript. This publication was made possible by the NSF Idaho EPSCoR Program, by the National Science Foundation under award numbers OIA-1826801 and OIA-1757324, and by the Bureau of Land Management under award numbers L16AC00137 and L17AC00306.

\section{Literature Cited}

Arkle, R.S., D.S. Pilliod, S.E. Hanser, M.L. Brooks, J.C. Chambers, J.B. Grace, K.C. Knutson, D.A. PyKe, J.L. WeLTY, AND T.A. WirTh. 2014. Quantifying restoration effectiveness using multi-scale habitat models: implications for sage-grouse in the Great Basin. Ecosphere 5:1-32.

Bajgain, P., B.A. Richardson, J.C. Price, R.C. Cronn, AND J.A. UDALL. 2011. Transcriptome characterization and polymorphism detection between subspecies of big sagebrush (Artemisia tridentata). BMC Genomics 12:370-385.

Connelly, J.W., M.A. Schroeder, A.R. Sands, and C.E. Braun. 2000. Guidelines to manage sage grouse populations and their habitats. Wildlife Society Bulletin (1973-2006) 28:967-985.
Fremgen-Tarantino, M.R., J.J. Peña, J.W. Connelly, AND J.S. FORBEY. 2020. Winter foraging ecology of Greater Sage-Grouse in a post-fire landscape. Journal of Arid Environments 178:104154.

Frye, G.G., J.W. Connelly, D.D. Musil, and J.S. Forbey. 2013. Phytochemistry predicts habitat selection by an avian herbivore at multiple spatial scales. Ecology 94:308-314.

Goodrich, S., E.D. Mcarthur, and A.H. Winward. 1999. Sagebrush ecotones and average annual precipitation. Pages 88-94 in E.D. McArthur, W.K. Ostler, and C.L. Wambolt, compilers, Proceedings: shrubland ecotones. USDA Forest Service Proceedings RMRS-P-11, Ogden, UT.

HART, N.S. 2001. The visual ecology of avian photoreceptors. Progress in Retinal and Eye Research 20:675-703.

Hart, N.S., AND D.M. Hunt. 2007. Avian visual pigments: characteristics, spectral tuning, and evolution. American Naturalist 169(S1):S7-S26.

Hitcheock, C.L., And A. Cronquist. 2018. Flora of the Pacific Northwest. 2nd edition. University of Washington Press, Seattle, WA. 936 pp.

Huynh, M.D., J.T. Page, B.A. Richardson, and J.A. UDALL. 2015. Insights into transcriptomes of big and low sagebrush. PLOS ONE 10(5):e0127593.

KNick, S.T., AND J.W. ConNelLY, EDITORS. 2011. Greater Sage-Grouse: ecology and conservation of a landscape species and its habitats. 1st edition. University of California Press, Berkeley, CA. 664 pp.

McArthur, E.D. 2005. Sagebrush, common and uncommon, palatable and unpalatable. Rangelands 27: $47-51$.

McArthur, E.D., AND S.C. SANDERSon. 1999a. Cytogeography and chromosome evolution of subgenus Tridentatae of Artemisia (Asteraceae). American Journal of Botany 86:1754-1775.

McArthur, E.D., AND S.C. SANDERSOn. 1999b. Ecotones: introduction, scale, and big sagebrush example. Pages 3-8 in E.D. McArthur, W.K. Ostler, and C.L. Wambolt, compilers, Proceedings: shrubland ecotones. USDA Forest Service Proceedings RMRS-P-11, Ogden, UT.

McArthur, E.D., B.L. Welch, and S.C. Sanderson. 1988. Natural and artificial hybridization between big sagebrush (Artemisia tridentata) subspecies. Journal of Heredity 79:268-276.

Olsoy, P.J., J.S. Forbey, L.A. Shipley, J.L. Rachlow, B.C. Robb, J.D. Nobler, and D.H. Thornton. 2020. Mapping foodscapes and sagebrush morphotypes with unmanned aerial systems for multiple herbivores. Landscape Ecology 35:921-936.

Requena-Mullor, J.M., K.C. Maguire, D.J. Shinneman, AND T.T. CAUGHLIN. 2019. Integrating anthropogenic factors into regional-scale species distribution models-a novel application in the imperiled sagebrush biome. Global Change Biology 25:3844-3858.

Richardson, B.A., A.A. Boyd, T. Tobiasson, and M.J. Germino. 2018. Spectrophotometry of Artemisia tridentata to quantitatively determine subspecies. Rangeland Ecology and Management 71:87-90.

Richardson, B.A., J.T. Page, P. Bajgain, S.C. Sanderson, AND J.A. UDALL. 2012. Deep sequencing of amplicons reveals widespread intraspecific hybridization and multiple origins of polyploidy in big sagebrush (Artemisia tridentata; Asteraceae). American Journal of Botany 99:1962-1975.

Rовв, B.C. 2020. Spectral fingerprints predict functional phenotypes of a native shrub. Boise State University 
Theses and Dissertations. https://doi.org/10.18122/ $\mathrm{td} / 1715 /$ boisestate

Rosentreter, R. 2005. Sagebrush identification, ecology, and palatability relative to sage-grouse. Pages 3-16 in N.L. Shaw, M. Pellant, and S.B. Monsen, compilers, Sage-grouse habitat restoration symposium proceedings. Proceedings RMRS-P-38, U.S. Department of Agriculture, Forest Service, Rocky Mountain Research Station, Fort Collins, CO.

Shafizadeh, F., AND A.B. Melnikoff. 1970. Coumarins of Artemisia tridentata ssp. vaseyana. Phytochemistry 9:1311-1316.

ShEeHy, D.P., AND A.H. WinWard. 1981. Relative palatability of seven Artemisia taxa to mule deer and sheep. Journal of Range Management 34:397-399.

Shultz, L.M. 2006. Artemisia: felon-herb, mugwort, sagebrush, sailor's tobacco, wormwood, armoise, herbe Saint-Jean. Flora of North America 19:503-534

Shultz, L.M. 2012. Pocket guide to sagebrush. PRBO Conservation Science, Petaluma, CA.

Stevens, R., And E.D. McArthur. 1974. A simple field technique for identification of some sagebrush taxa. Journal of Range Management 27:325-326.

Turi, C.E., P.R. Shipley, And S.J. Murch. 2014. North American Artemisia species from the subgenus Tridentatae (sagebrush): a phytochemical, botanical and pharmacological review. Phytochemistry 98:9-26.

Ulappa, A.C., R.G. Kelsey, G.G. Frye, J.L. Rachlow, L.A. Shipley, L. Bond, X. Pu, and J.S. Forbey. 2014. Plant protein and secondary metabolites influence diet selection in a mammalian specialist herbivore. Journal of Mammalogy 95:834-842.

Wambolt, C.L. 1996. Mule deer and elk foraging preference for 4 sagebrush taxa. Journal of Range Management 49:499-503.

Wambolt, C.L. 2001. Mule deer foraging preference among five sagebrush (Artemisia L.) taxa. Western North American Naturalist 6:490-494.
WELCH, B.L. 2005. Big sagebrush: a sea fragmented into lakes, ponds, and puddles. General Technical Report RMRS-GTR-144, U.S. Department of Agriculture, Forest Service, Rocky Mountain Research Station, Fort Collins, CO. 210 pp.

Welch, B.L., and E.D. McArthur. 1986. Wintering mule deer preference for 21 accessions of big sagebrush. Great Basin Naturalist 46:281-286.

Welch, B., F. Wagstaff, and J. Roberson. 1991. Preference of wintering sage grouse for big sagebrush. Journal of Range Management 44:462-465.

Wilt, F.M., J.D. Geddes, R.V. Tamma, G.C. Miller, and R.L. EvERETT. 1992. Interspecific variation of phenolic concentrations in persistent leaves among six taxa from subgenus Tridentatae of Artemisia (Asteraceae). Biochemical Systematics and Ecology 20:41-52.

Wilt, F.M., AND G.C. MiLLER. 1992. Seasonal variation of coumarin and flavonoid concentrations in persistent leaves of Wyoming big sagebrush (Artemisia tridentata ssp. wyomingensis: Asteraceae). Biochemical Systematics and Ecology 20:53-67.

WING, B., AND T. Messmer. 2016. Impact of sagebrush nutrients and monoterpenes on Greater Sage-Grouse vital rates. Human-Wildlife Interactions 10:157-168.

Winward, A. 2004. Sagebrush of Colorado: taxonomy, distribution, ecology and management. Colorado Division of Wildlife, Department of Natural Resources, Denver, CO.

Received 14 May 2020

Revised 7 November 2020

Accepted 8 December 2020

Published online 6 July 2021 